\title{
Funerais entre os Bororo. Imagens da refiguração do mundo
}

\author{
Sylvia Cainby Novaes \\ Professora do Departamento de Antropologia - USP
}

RESUMO: O objetivo do trabalho é analisar os funerais bororo como momentos de desfiguração e refiguração do mundo (Taussig, 1999). Entre os Bororo, a morte dá início a uma série de transformações que envolvem o morto, seu corpo, a alma, a escolha e investidura do representante do morto, assim como transformações nas relações sociais entre os vivos. Todas essas transformações, que são objeto de segredo público, são elaboradas ao longo dos rituais que fazem parte do ciclo funerário. O texto é acompanhado por uma seleção de fotos captadas por mim ao longo de trinta anos de pesquisa entre esses índios, de modo a ilustrar os funerais bororo como momentos de recriação do mundo, com base nas perspectivas teóricas elaboradas por Taussig (1999) e Overing (1989, 1990).

PALAVRAS-CHAVE: funerais entre os Bororo, processos de desfiguração e refiguração, segredo público, fotografias dos rituais funerários dos Bororo.

Boe nasceu para complicar. Nasceu põe nome, fura beiço dele se for homem. É a mesma coisa que faz quando ele morre. Morreu devia acabar tudo, mas começa tudo outra vez, porque tem cabacinha. Boe não quer acabar. (José Carlos) 
Caiuby Novaes, S. Funerais entre os Bororo...

Boe é como os Bororo se autodenominam. Essa frase me foi dita por um grande chefe bororo da aldeia Garças, e foi com ela que terminei um dos primeiros artigos que escrevi após meu mestrado. Ela resume de modo claro os grandes processos de transformação presentes nas concepçôes que os Bororo têm a respeito da sociedade e da pessoa, concepções que são dramatizadas e tornadas visíveis ao longo de seus inúmeros rituais funerários. ${ }^{1}$

De todos os eventos que marcam o ciclo da vida entre os Bororo, a morte é, certamente, a mais celebrada. Não há vida sem morte nessa sociedade. É nos funerais que são evocadas as almas de antepassados e de heróis culturais. Durante os ritos funerários, que podem se estender por três meses, entre a morte de uma pessoa e o enterro definitivo de seus ossos, os jovens são familiarizados com os valores que regem essa sociedade dual, são lembrados das regras de reciprocidade e iniciados efetivamente na vida adulta. O funeral é, nesse sentido, um momento muito propício para a produção e difusão do conhecimento - que se dá, como veremos, em moldes muito específicos. Os cantos, por exemplo, entoados em todos os rituais são elementos fundamentais da transmissão do conhecimento acumulado. São cantos que relembram a todos das façanhas dos heróis culturais, fundadores das regras da vida social, das disputas entre esses personagens míticos e do modo como foram resolvidas; os cantos rememoram os pontos geográficos mais importantes do território da sociedade bororo, os recursos aí existentes em termos de fauna e flora, as técnicas de caçada e pescaria. ${ }^{2}$ Como dizem os autores da Enciclopédia bororo, volume III, dedicada aos cantos, "Os cantos são o código dos feitos de heróis lendários, das instituições, dos adornos, das ações célebres de algum membro da tribo, intimamente ligado ao seu totem" (Albisetti \& Venturelli, 1976, p. 2). Dada a importância associada aos cantos, é fundamental que o cantador não cometa 
erros, e, se o encarregado de cantar é um jovem, sempre haverá alguém que sabe o canto atrás dele para socorrê-lo caso seja necessário.

Inúmeras são as transformações após uma ruptura tão brusca quanto a morte. É preciso restaurar o equilíbrio por ela ameaçado e, para esse enorme esforço, os grandes chefes convocam a sociedade bororo como um todo. A morte reúne a sociedade dos vivos à sociedade dos mortos. Parentes homens e mulheres de todas as várias aldeias se reúnem para as celebraçôes, e nesses momentos rituais todos os mortos dessa sociedade são relembrados por seus parentes vivos. Para os Bororo, tal como para os Kaxinawa, analisados por Els Lagrou (neste volume), os rituais, como veremos, não excluem o riso e o humor e são inúmeros os ritos e as celebrações em que impera o grotesco. Como diz Lagrou, se o poder provoca o riso, também o riso tem seu próprio poder. E é exatamente nesses momentos de bruscas transformaçóes que o riso pode se fazer presente.

São várias as perspectivas analíticas para a compreensão de rituais de modo geral e do funeral bororo em particular - perspectivas não necessariamente excludentes. Como bem o mostrou Viertler em $A$ refeição das almas (1991), os funerais têm implicações culturais, políticas, econômicas e adaptativas para a sociedade bororo. Em minha opinião, os funerais constituem também momentos muito especiais para essa sociedade, momentos de enorme força de expressão estética, seja por meio dos cantos, das danças ou dos ornamentos usados nessas ocasiōes. Momentos em que se renova o conhecimento produtivo e estético dessa sociedade, que, na perspectiva adotada por Overing (1991), permitem a manutenção da comunidade e provêm a força criativa para sua continuidade. Além de cantos e danças, os funerais entre os Bororo implicam atividades coletivas de caça, pesca e coleta. São também momentos de "ânimo inspirado", como diz Joanna Overing, em que o sentido de comunidade se reforça. 
Mary Douglas já afirmava em Pureza e perigo (1966) que, se a fala é capaz de criar pensamentos, os rituais podem criar percepção. Como se dá essa percepção? Douglas mostra que rituais fornecem um foco, um método mnemônico e uma possibilidade de controle da experiência. $^{3} \mathrm{O}$ ritual tem poder criativo em termos de performance e, se pensarmos no funeral bororo, seu foco é o corpo em todos os sentidos. A morte é a extinção do sopro vital, e é a partir desse fato que ações rituais são levadas a cabo, sempre tendo como centro a desfiguração e refiguração dos corpos - do morto e de seu representante, do próprio sopro que se extingue e é recriado pela cabacinha mortuária, soprada pelo representante, daquele que morre e do jovem que passa a adulto, por meio do ritual de iniciação realizado somente durante os funerais.

Os ritos funerários envolvem conhecimento e, tal como afirma Santos-Granero (neste volume) a respeito dos Yanesha, "instead of being the cause of knowledge [...] bodies are caused by knowledge", no caso Bororo, o conhecimento ritual. $\mathrm{O}$ ritual torna visíveis signos exteriores de estados interiores e, nesse sentido, é como se os sentidos do mundo passassem pelos sentidos do corpo. Creio que essa é também uma perspectiva adequada para se entender as implicações dos ritos funerários entre os Bororo, seja em termos dos processos de continuidade social eleitos por essa sociedade, seja em termos de sua força única de expressão estética, motivo de orgulho para os Bororo.

\section{Funeral bororo: possibilidades de uma etnografia por meio de texto e imagem}

Muito se escreveu sobre o funeral bororo - eu mesma já publiquei vários trabalhos sobre o tema. ${ }^{4}$ Essa literatura, entretanto, sempre me deu a sensação de incompletude. Se o texto explica, argumenta, analisa e 
Revista de Antropologia, São Paulo, USP, 2006, v. 49 no 1.

interpreta, não sendo poesia, pouco traz daquilo que mais está presente nos funerais bororo: a emoção, a estética, a catarse coletiva que impregnam essa sociedade nas diferentes fases desse ciclo. Revendo meus diários de campo, percebi que preenchi páginas e páginas sobre o cotidiano da vida na aldeia e o modo como me sentia ou reagia a cada dia. Quase não fiz comentários sobre o funeral. Imagino que não tivesse palavras para descrever nesses diários o que via e sentia. Por outro lado, meu acervo de fotos da pesquisa entre os Bororo contempla um número enorme de imagens sobre os ritos funerários em suas diferentes fases. Nos textos que publiquei, diversos aspectos do funeral são descritos, comentados, interpretados e analisados, mas praticamente não usei imagens. Meu objetivo agora é exatamente este: procurar aproximar o registro sensível de meu olhar sobre o funeral bororo às reflexões que desenvolvi ao longo destes trinta anos de pesquisa.

Por outro lado, foi por meio de um olhar mais detido para essas imagens que pude aprofundar alguns insights sobre, por exemplo, as relações entre os ritos funerários e o ritual de nominação nessa sociedade. Num certo sentido, as imagens permitem ver aquilo que não era imediatamente visível, não só porque possibilitam que se recorra a elas inúmeras vezes (o que é impossível na pesquisa de campo), mas também porque contêm um elemento mais sensível que o olhar seleciona.

As imagens dos funerais bororo, que captei ao longo de trinta anos de pesquisa de campo entre esses índios, foram selecionadas e ordenadas de modo a permitir a visualização das concepçóes que essa sociedade expressa em seus rituais funerários a respeito do longo processo de transformação que caracteriza a pessoa bororo, seus duplos e representantes, corpos e almas, pessoas e ancestrais. As imagens sobre o funeral bororo tornam ainda mais visível a relação entre corpo, ritual e conhecimento. Corpos que se desfazem ao serem regados em sua cova provisória, corpos refigurados na aparição do aroe maiwu, os corpos escarificados dos 
enlutados. Foram muitos os funerais que presenciei ao longo de minha pesquisa de campo, e posso dizer que assisti a todas as fases desse longo ciclo, desde o anúncio da morte de uma pessoa até o enterro definitivo de seus ossos em uma baía. Nunca assisti a um ciclo completo, mas presenciei todas as fases do funeral em diferentes momentos da pesquisa.

Restava uma questão: como apresentar imagens obtidas ao longo de trinta anos em funerais de pessoas muito diversas? Minha opção foi guiada pela concepção que os Bororo têm daquilo que ocorre em seus funerais: um encontro de todos os vivos e todos os mortos. A cada funeral, todas as pessoas mortas são lembradas por seus parentes vivos e por seus representantes rituais e, por meio da cabacinha tocada por esses representantes, todos se fazem presentes no funeral. Esta me pareceu a estratégia possível: ordenar as imagens a partir da cronologia de um modelo padrão do rito funerário, criando uma espécie de sincronia entre as fotos captadas ao longo de um período de trinta anos. Nesse sentido, as imagens trazem o meu olhar em diferentes momentos da pesquisa, mas foram selecionadas e apresentadas respeitando a seqüência ritual.

Qual a contribuição dessas fotos para a compreensão dos sentidos de um funeral para os Bororo? O que esta montagem de imagens poderia revelar que o texto puro e simples é incapaz de conter? Creio que alguns dos trabalhos de Taussig (1993 e 1999) podem nortear o que gostaria de apresentar neste aqui.

Na releitura dos trabalhos de Frazer e Benjamim, Taussig (1993) procura construir aquilo que ele denomina uma história particular dos sentidos, enfatizando especificamente as questões da alteridade e da mímesis. Instigado pela arte e pelo poder do faz-de-conta, Taussig procura compreender o quanto é real aquilo que é efetivamente construído simbolicamente. No caso aqui analisado, como elaborar, por exemplo, a figuração daquele que deixa de ser gente e passa a ser alma? Ou daquele que será considerado como o representante social do morto? A alma e 
Revista de Antropologia, São Paulo, USP, 2006, v. 49 no 1.

o representante social do morto devem ser tomados como realidades realmente construídas, cuidadosamente elaboradas pelos Bororo ao longo dos ritos funerários por meio de processos simbólicos que envolvem a mímesis e o contato.

Logo no início de Mimesis and alterity, Taussig define a mímesis como a natureza que a cultura utiliza para criar uma segunda natureza, a faculdade de imitar, copiar, criar modelos, explorar diferenças, entregar-se e tornar-se Outro. "The wonder of mimesis lies in the copy drawing on the character and power of the original, to the point whereby representation may even assume that character and that power" (1993, p. XIII). Retomando Frazer e trazendo-o para o que ocorre no mundo contemporâneo, Taussig mostra que cópia e contato são passos do mesmo processo: ver ou ouvir algo é estar em contato com esse algo (id., p. 21). "[...] in many, if not in the overwhelming majority of cases of magical practices in which the Law of Similarity or Imitation is important, it is in fact combined with the Law of Contact" (id., p. 55, grifo do autor).

A mímesis é parte desse processo de entregar-se e tornar-se Outro. Esse poder que em determinadas situações (a que Taussig analisa é a situação colonial) é intrínseco à mímesis e à alteridade pode ser uma força destrutiva, mas também uma força curadora. No caso que analiso, é possível pensar a situação de vida e morte, tal como a que é vivida no funeral, como uma situação de fronteira, de desequilíbrio, em que o caos pode se instalar. São várias as alteridades aí dramatizadas, e de certa forma é dessa dramatização que depende o restabelecimento da ordem quebrada pela morte: vivos e mortos, ecerae e tugarege - as duas metades que constituem a aldeia bororo -, criança e adulto, mas igualmente Boe (autodenominação dos Bororo) e Brae (termo utilizado para os não índios ou civilizados, como eles traduzem).

Para Taussig, é a mímesis que articula o real ao realmente construído, processo sem o qual nenhuma sociedade existe (id., p. 86). Essa arte 
mimética é parte do segredo público (public secrecy), algo inerente a todas as instituições sociais e que o autor desenvolverá em seu outro livro - Defacement (1999) -, no qual associa a desfiguração àquilo que ocorre quando algo muito precioso nos é retirado. A desfiguração, ao trazer as profundezas para a superfície, revela mistérios e traz a proximidade com o sagrado. Tal como Benjamim, Taussig vê uma relação entre segredo e verdade. Ou seja, a verdade não é uma questão de revelação ou desmascaramento que destrói o segredo, mas algo que lhe faz justiça (id., p. 2). Para Taussig, o segredo público, aquilo que todos sabem que não devem saber, é a mais importante forma de conhecimento social. Aquilo que se sabe, mas não se consegue articular. Daí também o interesse na utilização dessa abordagem que vincula imagens e textos para aquilo que dificilmente é formulado com relação ao funeral bororo.

\section{Primeiro enterro}

Os vários sentidos de defacement desenvolvidos por Taussig (1999) podem ser interessantes para refletirmos sobre o que ocorre durante o longo ciclo do funeral bororo. Vejamos cada um desses sentidos e como eles podem ser úteis para pensarmos as várias fases do funeral. A morte, como vimos, desencadeia um longo ciclo de transformações, e essas transformações devem ser controladas e vividas ritualmente pelos Bororo. Um dos sentidos de defacement é estragar a superfície ou aparência de algo previamente existente.

É, portanto, necessário figurar bem aquilo que será desfigurado. As marcas mais visíveis do pertencimento clânico são nitidamente impostas ao moribundo: seus cabelos são cortados do modo tradicional, seu corpo é todo untado de urucum, seu rosto ornamentado com pinturas, e em sua cabeça são colocados adornos plumários de acordo com 
Revista de Antropologia, São Paulo, USP, 2006, v. 49 no 1.

os padrōes do clã a que ele pertence. É preciso identificar claramente esse corpo e essa pessoa que serão desfigurados após a morte.

A perda do sopro vital é o sinal da morte. A partir do momento em que se constata a perda do sopro vital, o rosto do morto é coberto por uma bandeja de palha para que, transformado em aroe (alma), não seja visto por mulheres e crianças. Essa é a primeira da longa série de transformaçôes desencadeadas pela morte e que, como tal, deve ser mantida fora dos olhares de mulheres e crianças.

O corpo do morto é então enrolado em uma esteira e enterrado em cova rasa no páteo central da aldeia. Inicia-se o processo de defacementestragar a superfície ou aparência de algo previamente existente. A decomposição da carne do morto, cuja cova é diariamente regada para ace-

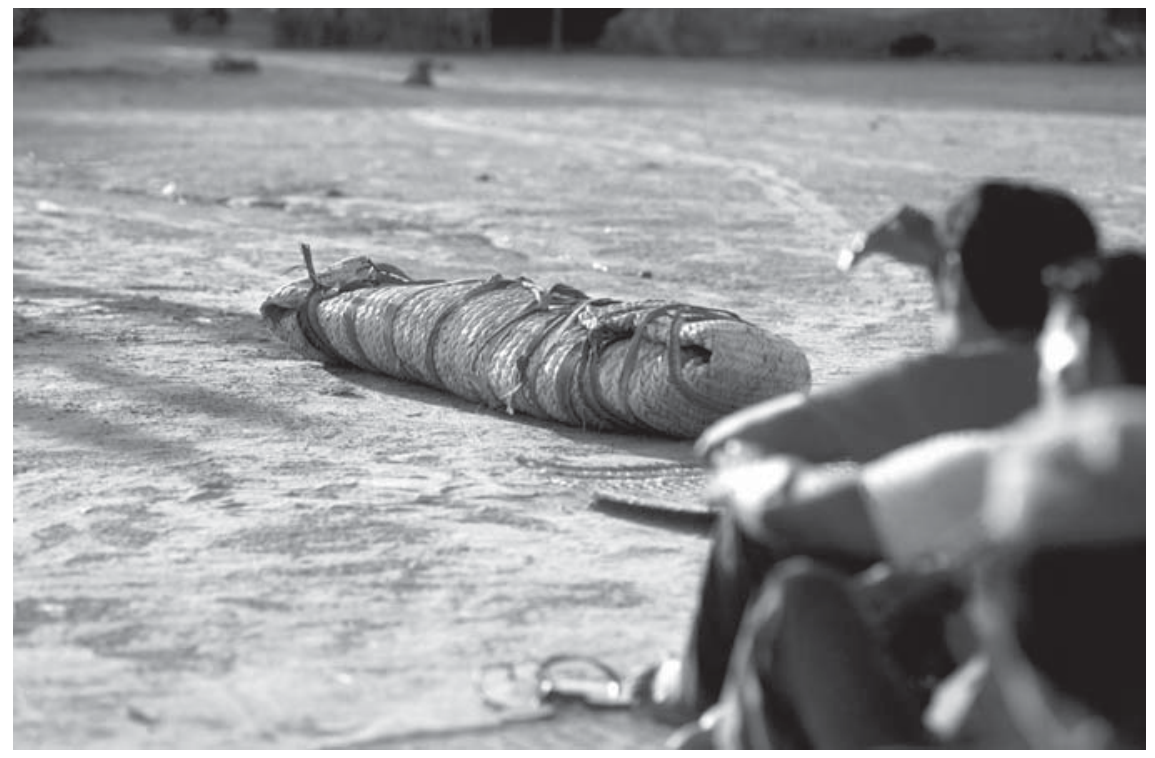

Figura 1: Envolto em uma esteira o corpo do morto é enterrado em uma cova rasa no páteo da aldeia. 
Caiuby Novaes, S. Funerais entre os Bororo...

lerar esse processo, é acompanhada de outros procedimentos que implicam igualmente defacement ou diminuir a utilidade, valor ou influência. Os pertences do morto serão ritualmente queimados pelo fogo ou destruídos - como as peças de cerâmica ou outros objetos que o fogo não destrói. Todos os elementos perecíveis do morto, desde a carne do próprio corpo até aquilo que ele possuía em vida, devem desaparecer após sua morte. Com a morte, nada disso tem valor ou utilidade nem pode ser transmitido como herança.

Se a criança é gestada no corpo materno e tem suas carnes fortalecidas pela contínua presença de sêmen, por meio de relações sexuais freqüentes ao longo de toda a gestação, o corpo enterrado nessa cova preparada pelas mulheres passará gradativamente a se decompor por meio das regas freqüentes dos homens da metade oposta a sua. Se as crianças ao receberem o nome têm seu rosto voltado para o local onde o sol nasce, o morto é enterrado com a face virada para o poente.

De tempos em tempos, essa cova é aberta para que se examine o estado do corpo e dos cheiros exalados. O cheiro de podre - jerimaga - é um dos índices de que o bope - espírito a quem se atribui todas as grandes transformações naturais, como o nascimento, a puberdade e a morte - ainda está lá, saciando-se com o corpo do morto. O bope é grande comedor de carne crua, cheia de sangue, e gosta de cheiros e carniça.

Até o enterro definitivo dos ossos, são muitos os cantos que se sucedem e eles ocorrem na casa do morto, na casa dos homens e no páteo central. Ao se deslocarem de um local para o outro, os participantes desses cantos seguem em fila, como que em comitiva, sempre encabeçados por alguém tocando flauta, maracás ou levando algum alimento ritual para as almas. 
Revista de Antropologia, São Paulo, USP, 2006, v. 49 no 1.

\section{Timbó}

Durante esse período inúmeros rituais são realizados, envolvendo praticamente toda a aldeia e seus convidados. Segundo Viertler, os bope, a quem se atribui a morte, são "senhores dos animais" associados a rituais de caça e de benzimentos do bari (o xamã bororo). Dentre os ritos funerários, alguns dos mais prestigiados são as caçadas e pescarias coletivas, sendo a pesca com timbó um dos mais importantes. Os ritos são atividades coletivas - a caça e a pesca exclusivamente masculinas - sempre precedidas de cantos e podem se estender por toda a madrugada até a hora da partida. Essas atividades evidenciam uma enorme cooperação entre os que delas participam. Ou, como diz Overing (1991), essas são atividades em que o ânimo inspirado fortalece e explicita o sentido de coletividade.

Quando caçam, pescam, dançam em seus rituais, os Bororo deixam de ser seres comuns. É como aroe $e^{5}$ que eles fazem essas atividades. Caçadas e pescarias ao longo dos funerais são certamente atividades de subsistência, mas é de modo ritual que são realizadas. $\mathrm{O}$ aspecto ritual e coletivo dessas atividades é fundamental no sentido de permitir a todos a percepção da sociedade de que participam e o modo específico como essa participação se dá. Tal como ocorre com os Muinane, da Amazônia colombiana, descritos por Londoño Sulkin (neste volume), são esses rituais, grandes ou pequenos, que explicitam como "Real People were made, shaped or healed, to ensure their health and sociability". Na mata, à beira da margem de rio ou lagoa, os aroe caçam, pescam, utilizam-se também de armadilhas para pegar os peixes. Podem passar o dia inteiro fora e, antes de voltar à aldeia, alguns dos peixes já são assados no próprio local para saciar a fome. 
Caiuby Novaes, S. Funerais entre os Bororo...

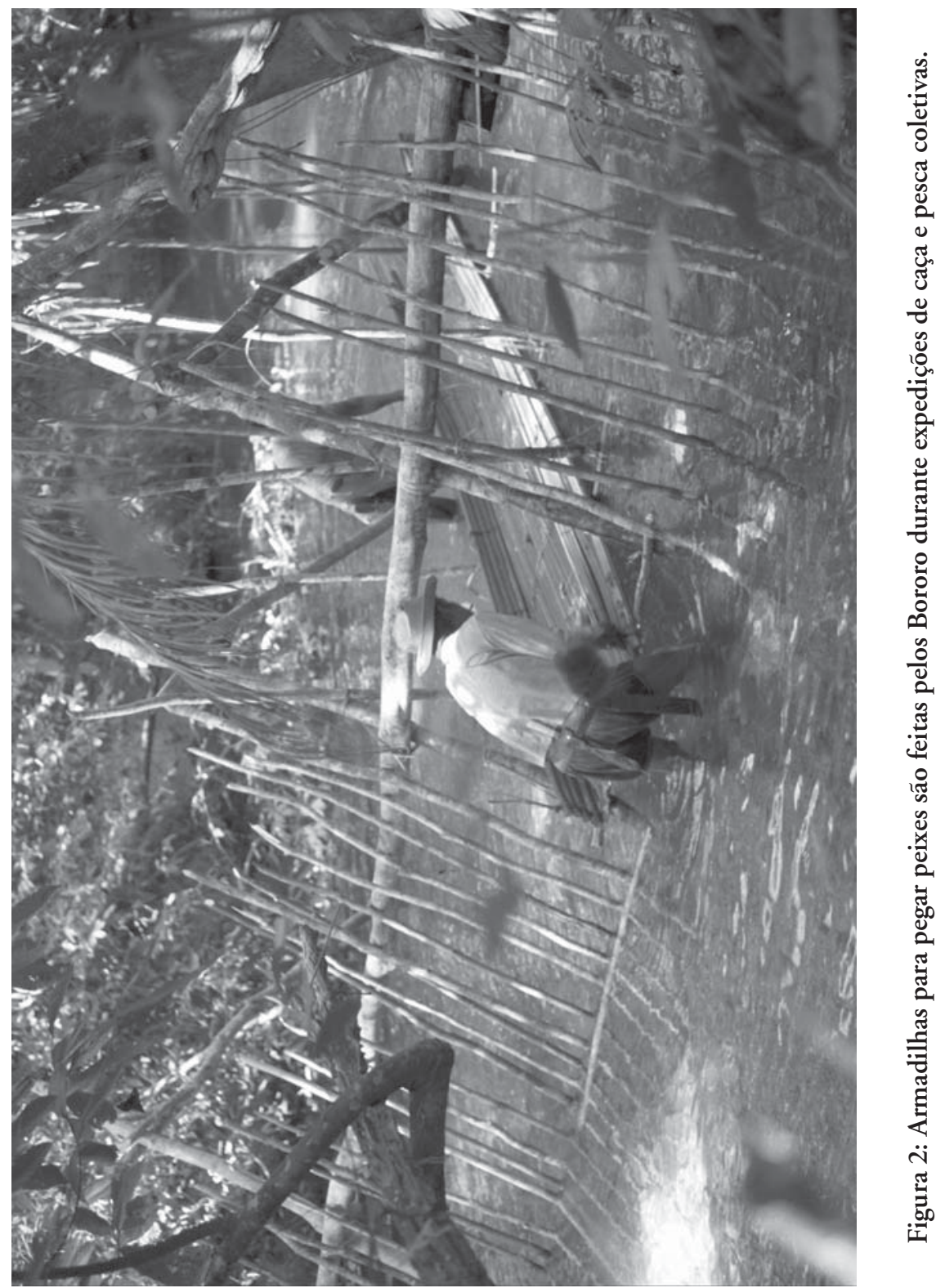




\section{Pinturas corporais}

Os rituais funerários são como que formas de reconstrução da sociedade bororo desequilibrada pela morte. Nesses rituais é possível reconstruir a sociedade por meio de cantos e danças. Os ritos funerários são, nesse sentido, momentos de reafirmação da relação de oposição e complementaridade entre as duas metades em que se dividem a aldeia e a própria sociedade bororo: os ecerae e os tugarege, cada uma dessas metades composta de quatro clãs. Cada um destes se caracteriza por possuir um patrimônio de nomes, cantos, danças, ornamentos corporais e representaçōes rituais. O clã que é "dono" de uma representação ritual deverá providenciar tudo aquilo que for necessário para que ela ocorra: o urucum, o jenipapo e a tabatinga para as pinturas corporais, os adornos, a palha com que são feitas as saias, as penas para os adornos plumários. Mas a representação ritual caberá ao clã da metade oposta àquele que a possui. Finda a representação, todos os adornos utilizados são colocados sobre a cova do morto, tornando visível a homenagem celebrada para que sua alma possa ir mais tranqüila habitar a aldeia dos mortos.

Nessa perspectiva, os rituais não apenas expressam idéias abstratas a respeito da sociedade bororo e procuram reconstruí-la, mas igualmente realizam coisas, produzem efeitos sobre o mundo, são trabalhos efetivamente executados. ${ }^{6}$

\section{Bakororo e Itubore}

Bakororo e Itubore são dois dos principais heróis míticos dos Bororo, também denominados por eles de aroe. Essa representação ritual retoma o próprio ato constitutivo da sociedade bororo - e, por essa razão, deve necessariamente ser realizada nos funerais. Bakororo, o mais importante, é do clã dos Aroroe cobugiwuge e é quem cuida do lado oci- 
dental da aldeia dos mortos, organizada de modo muito semelhante ao da aldeia dos vivos. Esse aroe usa sempre um instrumento de sopro denominado $i k a$, uma grande flauta. Bakororo tem como atributos a grandeza, a força e uma pintura corporal que combina listras vermelhas e pretas. O vermelho é a cor do raka, a força vital, e o preto é também força, mas força destrutiva que transforma degenerando (Crocker, 1985, p. 183). Cabe a Bakororo anunciar as festas, refeições e danças relativas às almas dos mortos.

Itubore é do clã dos Apiborege cebegiwuge e cuida do lado oriental da aldeia dos mortos. O instrumento de Itubore, também de sopro, é denominado pana e compõe-se de três cabaças, unidas por resina, com listras cobertas de penugem branca. Também as listras da pintura corporal de Itubore têm as bordas recobertas por uma penugem branca. Ele é quem anuncia as caçadas e pescarias das almas. Itubore e Bakoro são os heróis que recebem as almas dos finados.

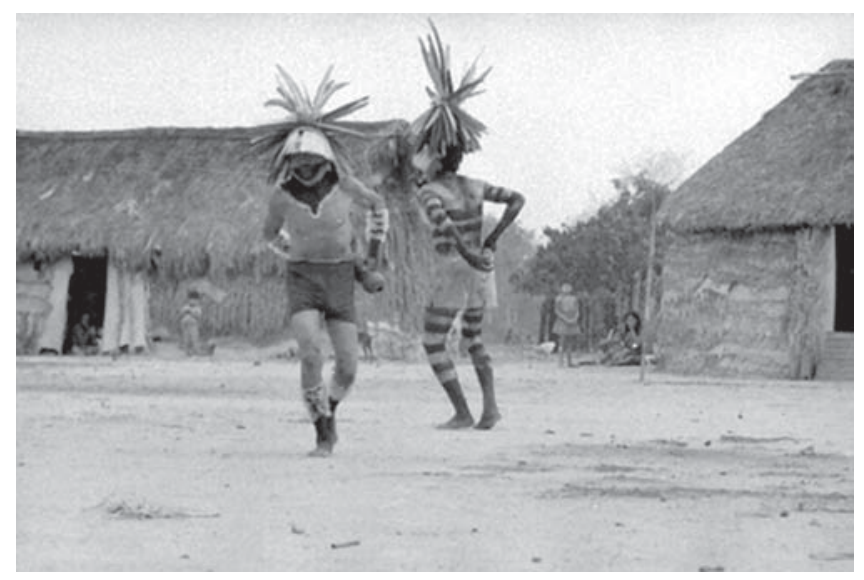

Figura 3: Bakororo and Itubore são os dois principais heróis míticos que criaram tudo aquilo que é importante para a sociedade Bororo. Neste ritual eles recriam este ato criador. 
Revista de Antropologia, São Paulo, USP, 2006, v. 49 no 1.

Os outros personagens rituais nas fotografias, que também prestam homenagem ao morto nos funerais, são os heróis míticos Bokwojeba e Bure Ikabéo. Bokwojeba tem o corpo todo coberto por uma tinta de carvão negro, sobre a qual são pintadas inúmeras pintas brancas feitas com um barro branco - noa (tabatinga). Na cabeça, na cintura, no bíceps, nos pulsos, abaixo dos joelhos e nos tornozelos, são amarrados brotos da palmeira de babaçu. Bure Ikabéo tem seu cabelo, rosto e corpo cobertos por uma pasta vermelha de urucum. Os braços e as pernas, até a barriga da perna, são recobertos de carvão com manchas brancas. Do rosto até o peitoral, o carvão preto é também pintado de grandes manchas brancas. Tal como Bokwojeba, Bure Ikabéo também tem as amarras do broto de babaçu.

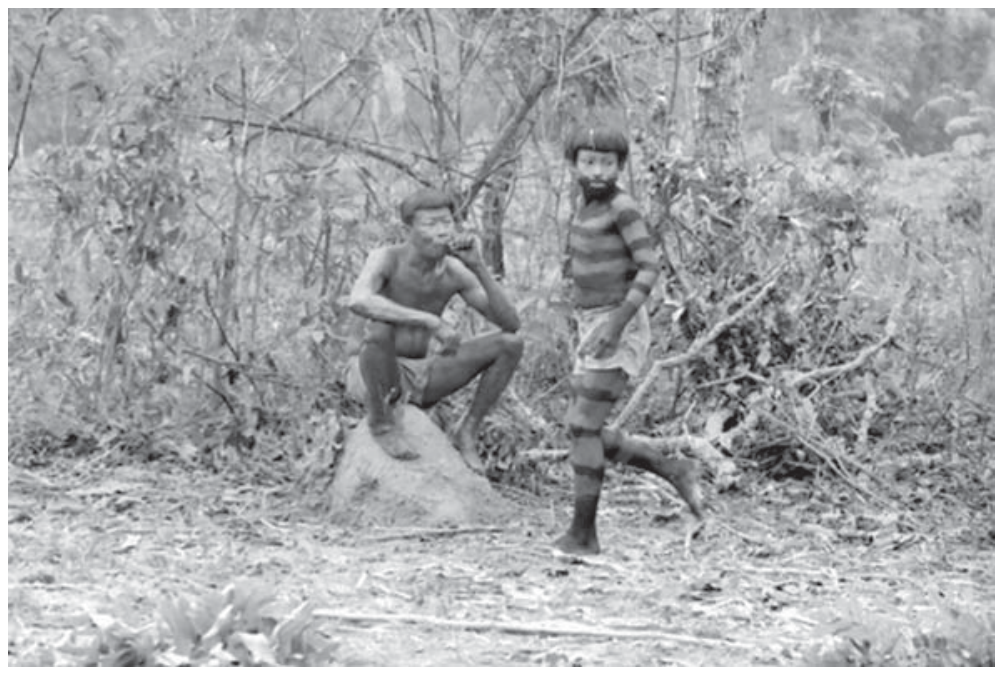

Figura 4: Durante os ritos funerários os Bororo pintam-se como seus heróis míticos; estes rituais são parte deste esforço para recriar a sociedade. 
Essa representação ritual traz para os funerais os grandes ancestrais que estabeleceram as bases da organização social bororo, que a morte impõe que seja recriada. Essa recriação é também uma reconstrução estética do mundo - que é muito específica e marca e distingue a sociedade bororo das demais. É neste sentido que o mundo deve ser "refeito": recriado por meio dos ritos e cantos funerários, realizados pelos grandes personagens míticos que deram à sociedade bororo as suas características específicas. Bakororo e Itubore estabeleceram o modus operandi da organização social dessa sociedade, definindo as relações entre as duas metades que a constituem, colocando o homem como pivô no equilíbrio dinâmico entre os princípios aroe e bope e reafirmando o poder simbólico da sociedade sobre fatos da natureza. Os homens morrem, e esse é um fato natural. Mas o representante do morto, que os Bororo denominam aroe maiwu, alma nova, continuará caçando e dando os animais abatidos a seus pais rituais, o que evidencia a presença contínua do morto na comunidade dos vivos (id., p. 280).

\section{Mano, Iwodu, Baraedu Ku Kuri}

A escolha dos ritos a serem celebrados ao longo do ciclo funerário depende do clã do finado e da disponibilidade de recursos materiais para realizá-los. Presenciei ao longo destes trinta anos vários desses rituais, como a corrida de toras de buriti - ou a corrida de mano, como eles denominam -, o ritual de Iwodu, em que os homens aparecem recobertos por folhas (de uma grande árvore da floresta chamada tatajuba), e uma pantomima em que os civilizados são representados como seres barrigudos, que falam e gesticulam muito - o Baraedu Ku Kuri.

A pantomima Baraedu Ku Kuri faz parte dos ritos funerários. Os Bororo reconhecem plenamente o poder do "mundo civilizado", mas é 
baseado no excesso que esse mundo é ritualmente caracterizado. $\mathrm{O}$ humor grotesco impera nesse ritual, tal como ocorre entre os Kaxinawa. Temporariamente, de modo jocoso, os Bororo tornam-se este outro, alteridade que tanto marca seu modo de ser. A paródia do mundo civilizado, povoado por seres barrigudos, pesados e que falam e gesticulam demais estabelece o grande contraste com o ritual em que aparecem as almas novas, os aroe maiwu, esses seres leves e esplendorosos.

Nessas representações rituais - aroe etawujedu -, os Bororo são aroe, personificam seus ancestrais míticos e cabe a eles, tal como os aroe fizeram em tempos míticos, a reconstrução da sociedade bororo. Se a morte desfigura, o mundo deve ser refigurado. Para confrontar o caos instaurado pela morte, é preciso recriar as danças, os cantos, a cultura material, em especial os belos adornos plumários - pariko -, uma vez que as almas se escondem neles. Os aroe etawujedu são, assim, represen-

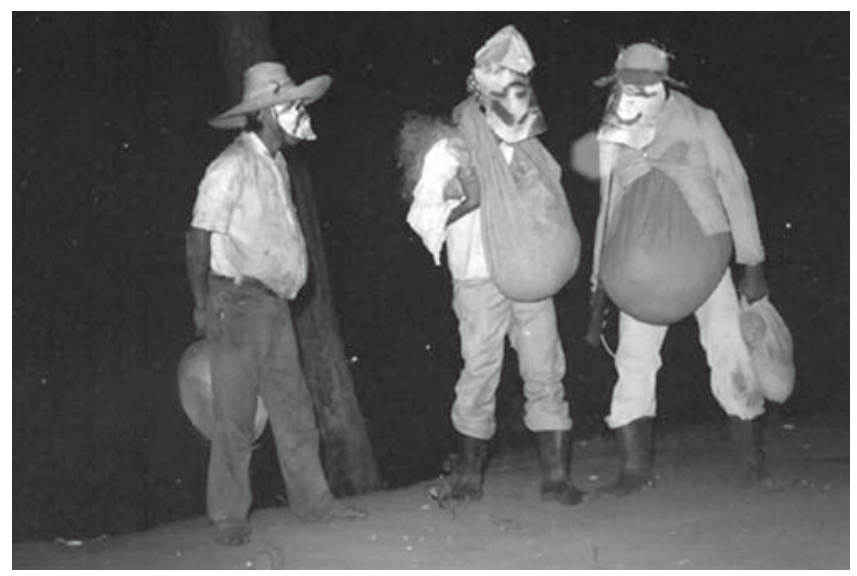

Figura 5: Os "homens civilizados" são representados pelos Bororo como seres desajeitados e barrigudos. 
Caiuby Novaes, S. Funerais entre os Bororo...

tações que reúnem vivos e mortos, as almas ancestrais, que estão lá presentes, dançando ao som dos maracás. Esses ancestrais, segundo Viertler, chamados por cantos e danças,

[...] voltam para visitar a aldeia dos vivos. Circulam em volta do túmulo, carregando seus bastôes, cavadeiras, taquaras ou demais objetos, emitindo gemidos característicos, revivendo cerimonialmente as suas guerras e lutas contra os inimigos mortais. [...] Os dançarinos não falam, apenas emitem gemidos ou gritos, sendo controlados em seus movimentos circulares em volta do túmulo pelas batidas dos chocalhos dos Roia Epa. (Viertler, 1991, p. 92 e 93$)$

Ao final das representações, todos os adornos plumários, as folhas e saias são colocados sobre o túmulo do morto. "Espera-se que as homenagens sejam do agrado do morto para que este, recebendo tudo o que lhe poderia ser dado (enfeites, danças, cantos, bebidas e comidas das almas), deixe de molestar com perigos os sobreviventes" (id., p. 94).

\section{Aroe Maiwu}

O que permanece da pessoa morta é a categoria social a que ela pertencia, que será representada pela "alma nova", o aroe maiwu - escolhido pelos homens mais velhos após a morte dessa pessoa e que deverá ser alguém da metade oposta à do morto. Este passa a ter também um casal de pais rituais, sendo o aroe maiwu tratado como filho desse casal.

A escolha do aroe maiwu é assunto dos homens, principalmente dos mais velhos do clã do morto. Como ocorre em todas as grandes transformações que têm lugar ao longo do funeral bororo, a construção simbólica dessa alma nova é um segredo, a que mulheres e crianças não de- 
vem ter acesso. Ornamentado no interior da casa dos homens, é preciso cuidado em cobrir de penugens e penas todos os traços do corpo que permitiriam reconhecê-lo: mãos, braços, pés e principalmente o rosto, que, além de receber os belos diademas de penas - os pariko -, é coberto por uma viseira de penas amarelas de japu. Mesmo que muitos saibam quem será o representante do morto, esse assunto é tratado como um grande segredo.

$\mathrm{O}$ aroe maiwu é, assim, alguém sem rosto. Essa alma nova, que no ritual se transforma no representante do morto, deverá se encarregar de várias atribuições, dentre as quais caçar um grande felino - onça-pintada, onça-parda ou jaguatirica -, cujos dentes e couro deverão ser oferecidos à família do finado como vingança pela perda sofrida.

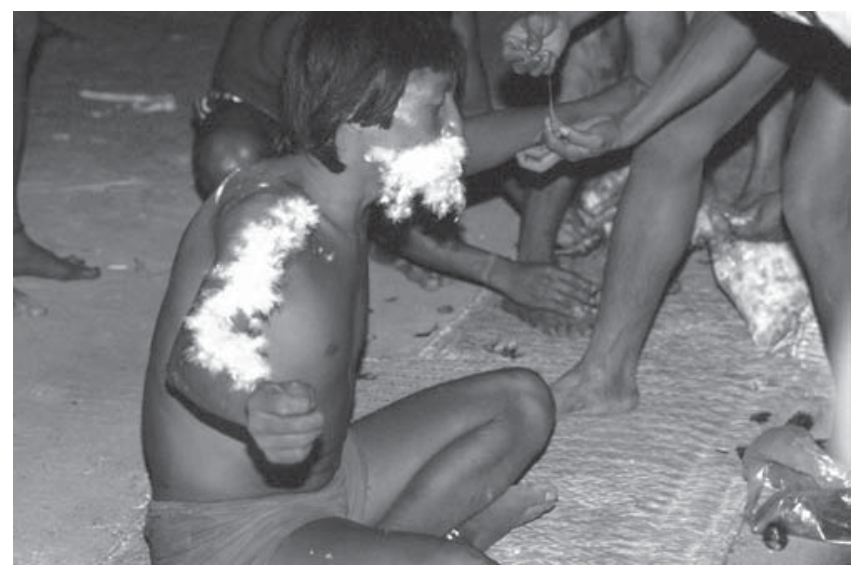

Figura 6: $\mathrm{O}$ homem escolhido para ser o representante do morto é ornamentado na casa dos homens. Seu corpo é totalmente coberto de penugem, penas e uma saia de palha, de modo que ninguém possa reconhecê-lo. 
Caiuby Novaes, S. Funerais entre os Bororo...

"A verdade não é um modo de exposição que destrói o segredo, mas uma revelação que faz justiça a ele", diz Taussig retomando Walter Benjamim. Porém, para os Bororo, essa verdade não é exatamente um segredo particular ou pessoal, mas um segredo público - todos sabem aquilo que não se deve saber, aquilo que não pode ser dito. Não se pronuncia o nome do morto após sua morte - este é mais um dos inúmeros traços de sua vida que deve desaparecer. As mulheres não devem saber quem é o representante do finado. Esses segredos, por todos compartilhados, são, como diz Taussig, a base das instituições sociais, do lugar de trabalho, da família, do estado. A desfiguração que ocorre nos funerais revela o mistério por trás da vida e da morte nessa sociedade. A morte desequilibra o cosmos, e é preciso um enorme esforço coletivo para que a vida retome seu rumo. A desfiguração é total - o corpo do morto, seu nome, seus pertences.

Cabe à alma nova, o representante do finado, um papel ativo nessa desfiguração e posterior refiguração do morto. Além de dançar e cantar, é ele que deve se encarregar de lavar os ossos do morto para que, ornamentados, possam ser rearranjados e definitivamente colocados num grande cesto e enterrados. Toda essa atividade relativa aos corpos envolve um profundo conhecimento ritual, e, nesse sentido, como afirma Granero, os corpos são literalmente produzidos por esse conhecimento. Essas são tarefas perigosas, e o representante receberá inúmeros enfeites da família do finado, um arco ritual, nomes e a possibilidade de se casar com uma mulher do clã do morto. Quanto maior o prestígio do finado, mais cuidadosa será a escolha do representante, para que este se desincumba a contento de suas tarefas, liberando assim o luto.

Assim, a desfiguração é, ela própria, acompanhada permanentemente por um processo de refiguração. "A desfiguração é privilegiada entre estas artes da magia porque ela oferece o caminho mais rápido para o componente mimético da magia simpática, na qual a representação se 
Revista de Antropologia, São Paulo, USP, 2006, v. 49 no 1.

transforma no representado, apenas para que o outro morra" (Taussig, 1999, p. 4). Ao dançar no páteo central, o aroe maiwu carrega algum objeto que pertencia ao morto e que o identifica de alguma forma: um arco se ele representa um homem, um cesto ou bandeja de palha (como se vê em uma das fotos) se está representando uma mulher, um brinquedo se o morto é uma criança. Essa relação de contigüidade (do objeto com seu antigo proprietário) e contato entre o representante e a pessoa que ele representa baseada nesse objeto, atestada por um único elemento, posto que todos os outros são destruídos, é o suficiente para estabelecer o elo da longa cadeia de transformações que a morte desencadeia. Se a morte provoca a desfiguração, no sentido literal da palavra, e é esse processo que os Bororo acompanham e controlam enquanto realizam seus vários rituais até que a carne do morto se decomponha e seus ossos possam ser ornamentados, ela permite igualmente a refiguração ou o remascaramento, para usar o termo de Taussig.

O aroe maiwu é agora o verdadeiro representante do morto e, para fazer justiça ao segredo que ele representa, é de forma esteticamente esplendorosa, resplandecente como o astro sol, dançando com movimentos leves, invariavelmente puxados por um homem que toca maracás, que ele surge no páteo central da aldeia. Ao participarem dos ritos funerários, todos os homens são aroe, aqueles heróis míticos que deram à sociedade bororo suas feições socioculturais específicas. Não se transformam em aroe, eles o são. Há uma natureza surreal no real ou, como diria Lévi-Strauss (1997), uma sobrenatureza nessa natureza.

A dança do aroe maiwu é a expressão ritual da mais importante transformação desencadeada pela morte: a presença (do finado) que se transforma em representação refigurada. Ao contrário do Bope, que come carne crua e sangrenta, os Aroe gostam de carnes cozidas, caldos, água doce - a comida das almas, servida pelas mães de aroe durante os funerais. 
Caiuby Novaes, S. Funerais entre os Bororo...

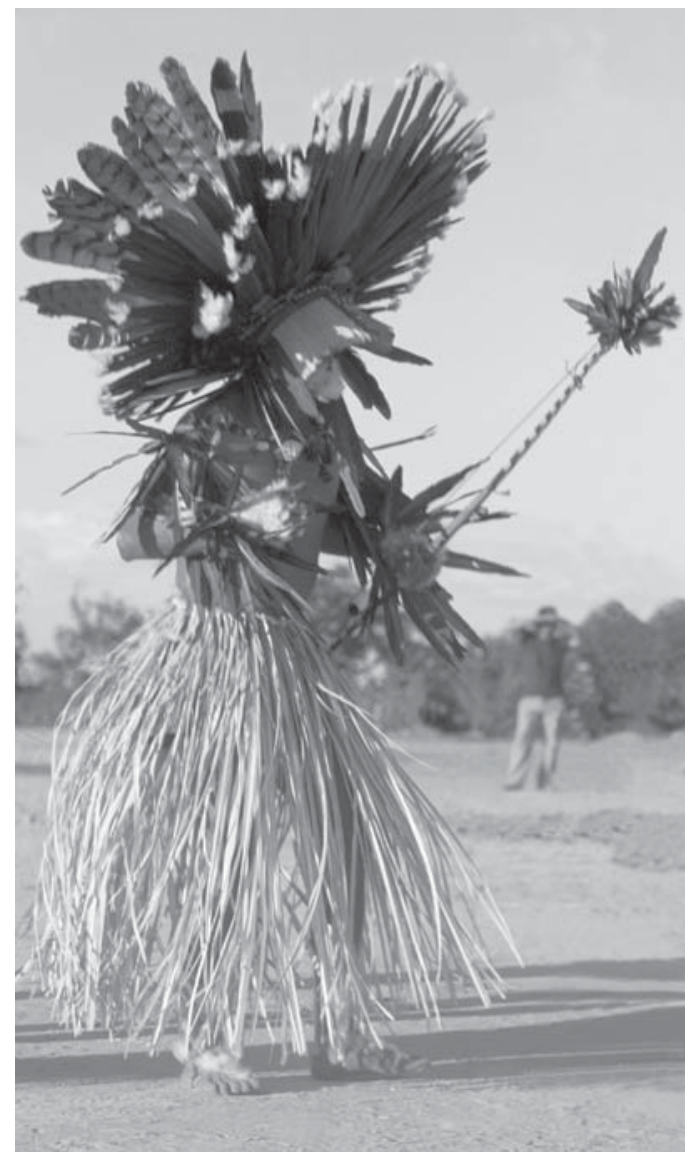

Figura 7: $\mathrm{O}$ aroe-maiwu (alma nova) agora está pronto. Como o verdadeiro representante do morto, ele parece um sol esplendoroso e surge em um ritual que ocorre no páteo central da aldeia. 
Revista de Antropologia, São Paulo, USP, 2006, v. 49 no 1.

\section{$\mathrm{O}$ ritual dos aije-doge aroe}

A dança da alma nova termina numa clareira próxima à aldeia, denominada aije muga, que se situa a leste, reino de Bakororo, o grande chefe das almas e dessa parte da aldeia dos mortos. Lá o representante do finado é aguardado por homens com o corpo coberto de tabatinga, que agitam os zunidores aije, previamente pintados e restaurados. Alguns dos homens têm caveiras de animal na cabeça, a face com um xis de jenipapo, o signo dos aije, que lembra os traços da onça.

Enquanto as carnes do morto se transformam pela decomposição, nesse processo de passagem de boe (autodenominação bororo que quer dizer gente) para aroe (alma), os rapazes a serem iniciados durante o funeral são transformados pelo ritual, quando passam de crianças a jovens adultos. Os rituais de iniciação ocorrem sempre nessa fase do funeral. É durante esse ritual dos aije que os rapazes são iniciados por seus iedaga (padrinhos) e convidados a presenciar pela primeira vez os aroe e zunidores, objetos fálicos, cuja visão é interditada às mulheres e crianças. ${ }^{7}$ É a iniciação que permite o acesso aos segredos do mundo ancestral, a que as mulheres e crianças não têm acesso, e é apenas após esse momento que os jovens, transformados em adultos pelo ritual do aije, podem ter uma mulher da metade oposta à sua, com a qual terão filhos.

Se a pantomima do mundo civilizado é marcada pelo humor grotesco, o ritual do aije, que leva à iniciação dos rapazes, é marcado pelo universo da sexualidade. "O aije disse que as mulheres e crianças não poderiam vê-lo. A mulher que o visse ficaria com a barriga inchada, com a perna mole, ficaria se arrastando no chão", disse-me Ukewai, grande líder dos Bororo. $\mathrm{O}$ fato de as mulheres que desafiam a interdição e presenciam essa representação ficarem "com a barriga inchada" é um claro sinal de que elas também não gozam de autonomia para decidirem sobre sua vida sexual. A "barriga inchada", ou a gravidez indesejável, é 
Caiuby Novaes, S. Funerais entre os Bororo...

acompanhada por sensações típicas: o cansaço das pernas, que parecem moles, e o peso do bebê, que dá à mulher a sensação de que está se arrastando. Assim, a gravidez é indesejável na medida em que escapou às regras pelas quais a sociedade bororo decide como quer se reproduzir.

Os iniciandos recebem de seus "padrinhos" (iorubadare, um homem da metade oposta à do iniciando e que pertence ao subclá em que o rapaz poderá escolher a própria esposa) um estojo peniano, que os Bororo denominam bá (mesmo termo, aliás, que eles utilizam para designar a casa, lembrando ainda que é com o casamento que o rapaz se transfere para a casa de sua esposa). Ao final desse ritual, pintados de branco, os homens se abraçam e se esfregam mutuamente em clima de grande algazarra e sensualidade.

Nesse sentido, a iniciação não define apenas o momento a partir do qual os jovens passam a ter uma vida sexual legítima e prolífica, mas igualmente as parceiras adequadas para a geração da prole. As dramatizações vividas nesse ritual permitem perceber as oposições maduro/ imaturo, proibido/prescrito, homem/mulher, vida/morte. O ritual é, assim, constituído por um conjunto articulado de significados que geram modelos de conduta, que, num certo sentido, se inscrevem nos corpos dos indivíduos. O ritual termina quando um homem, do clã dos Aroroe, bate uma esteira enrolada no chão do páteo central da aldeia. É o sinal para que as mulheres e crianças saiam de suas casas. ${ }^{8}$

Ao término desse ritual, os bens do morto que ainda não tiverem sido destruídos são reunidos no páteo central e queimados em uma enorme fogueira. "[...] após a queima dos objetos do Aroe, ao final do aijedoge aroe, a alma do morto perde as suas características culturais e antropomorfas" (Viertler, 1991, p. 138). Do morto sobram agora apenas seus ossos, que serão ornamentados depois de limpos, e a categoria social a que ele pertencia, agora tornada visível por meio do aroe maiwu. 


\section{A ornamentação dos ossos}

No dia seguinte ao ritual dos aije, os ossos do morto são levados a um rio, onde deverão ser cuidadosamente lavados. Já limpos, eles são levados num cesto de volta à aldeia, onde são recebidos pela mãe ritual do morto, que carrega a cesta com os ossos para a casa dos homens.

A ornamentação dos ossos ocorre no interior de um tabernáculo, construído com paredes de palha dentro da casa dos homens. Essa é também uma atividade propiciadora de transformação: de simples ossos a alma e, como tal, um segredo que não deve ser presenciado por mulheres e crianças, daí ser realizada no interior do tabernáculo. Cabe ao aroe maiwu, representante do morto, tingir de urucum os ossos maiores e o crânio, que recebe especial atenção, sendo não só pintado de urucum como recoberto de penas, num arranjo que segue o padrão clânico do morto ou de alguém que ele representava. Essa ornamentação dos ossos é acompanhada de cantos, choro ritual e escarificação das mulheres. Esse é o momento mais solene do funeral, e o que se presencia é uma verdadeira catarse coletiva.

Ornamentados, os ossos serão colocados em uma bandeja de palha, que é passada aos parentes do finado, que a carregam como se fosse um bebê e choram copiosamente, escarificando-se. Todos os ossos já pintados e ornamentados são colocados nesse grande cesto, o aroe j'aro, de acordo com uma ordem que procura reproduzir a ordem anatômica do corpo. Um cantador experiente, o aroe etawari are, xamã das almas, evoca a alma do finado para que esta ocupe agora sua nova morada, o cesto que foi especialmente preparado para isso. Todas as outras almas são também evocadas para que ajudem o morto a entrar na aldeia dos mortos. 


\section{O sepultamento definitivo}

O grande cesto com os ossos é costurado na borda e amarrado com as tranças dos cabelos de parentes de alguma pessoa falecida que o finado representava. Uma embira é também colocada no cesto, para que este possa ser transportado. A mãe ritual do morto carrega então o cesto pela casa dos homens e depois o leva para o grande páteo central, percorrendo todo o círculo de casas da aldeia. Esse trajeto é feito na direção inversa daquela de uma mãe que carrega seu bebê pela aldeia logo depois que ele recebe o nome. E, se a jovem mãe apresenta o filho que acabou de receber o nome logo pela manhã, é quando o sol se põe que o morto é carregado por sua mãe ritual pela aldeia, que o apresenta às diferentes

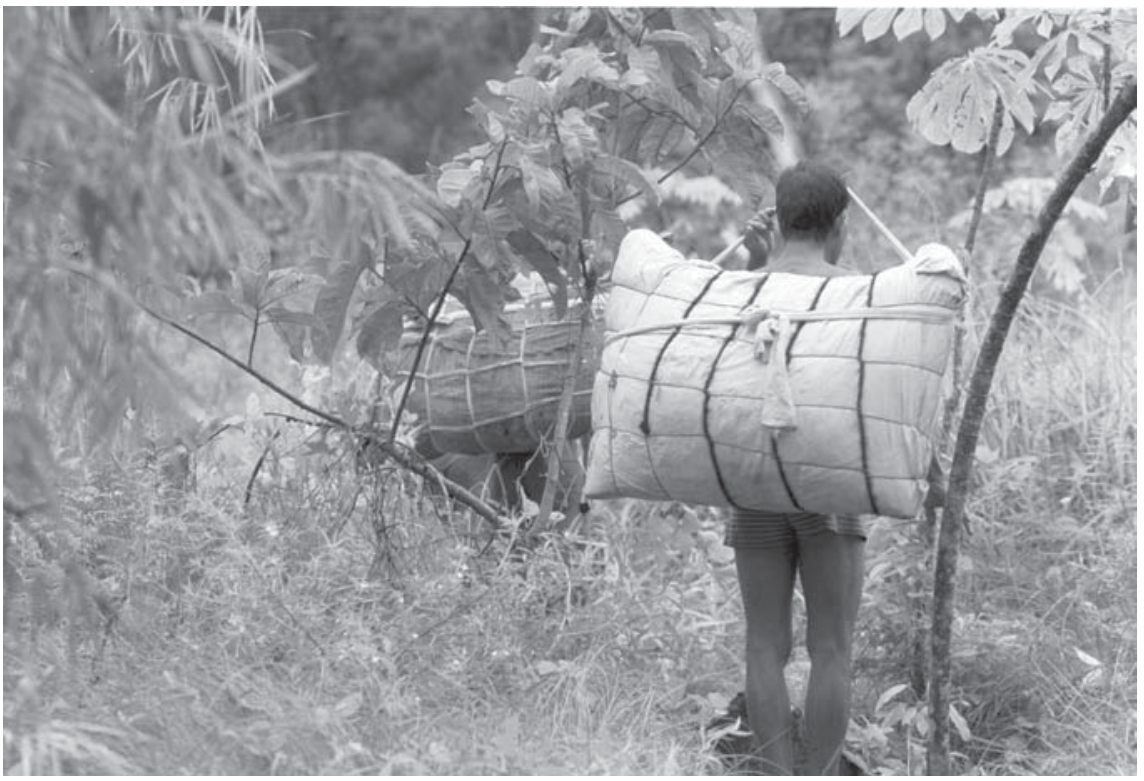

Figura 8: Os ossos do morto são pintados e arranjados em um grande cesto, que é então levado a uma baía onde deve ser afundado na água. 
casas, agora já na forma de aroe. Depois dessa volta, ela leva o cesto para sua casa, onde os ossos deverão descansar por alguns dias até serem levados a uma baía. Do sepultamento definitivo, feito logo pela manhã, encarrega-se o aroe maiwu. O cesto é levado a uma baía, perfurado para que a água penetre mais facilmente e enterrado.

\section{Barege eke dodu}

O luto só termina quando o morto é devidamente vingado por seu representante. Munido de arco, flechas e com as tranças do cabelo dos enlutados amarradas em seu punho, o aroe maiwu deverá caçar um grande felino, cujos dentes, garras e couro serão entregues aos parentes do finado. Ao morrer, o animal perde seu sopro vital, que se aloja então na cabacinha mortuária, fabricada pelo pai ritual do morto e que será então tocada pelo caçador. É a essa cabacinha que se refere a epígrafe deste artigo. ${ }^{9}$

A alma de um finado abriga-se, para os Bororo, em corpos de animais, nos quais se vinga comendo as comidas do bope. Depois de caçado, o couro desse animal é entregue à mãe ritual do morto, que então chorará ritualmente. A entrega do couro e das garras do felino aos parentes masculinos do morto e dos dentes às mulheres do clã do finado representa o mori, a retribuição que o finado envia aos parentes, por meio de seu representante, como recompensa pelos serviços funerários que lhe foram prestados. Esse ritual termina com a dança entre o caçador aroe maiwu e a mãe ritual - a dança "consagra a reciprocidade entre 'mães' e 'filhos' rituais, sexualmente interditados" (Viertler, 1991, p. 142).

Em todos os funerais, a cabacinha, powari aroe, será tocada pelo representante do morto, que estará então participando como aroe da vida da aldeia. 
Caiuby Novaes, S. Funerais entre os Bororo...

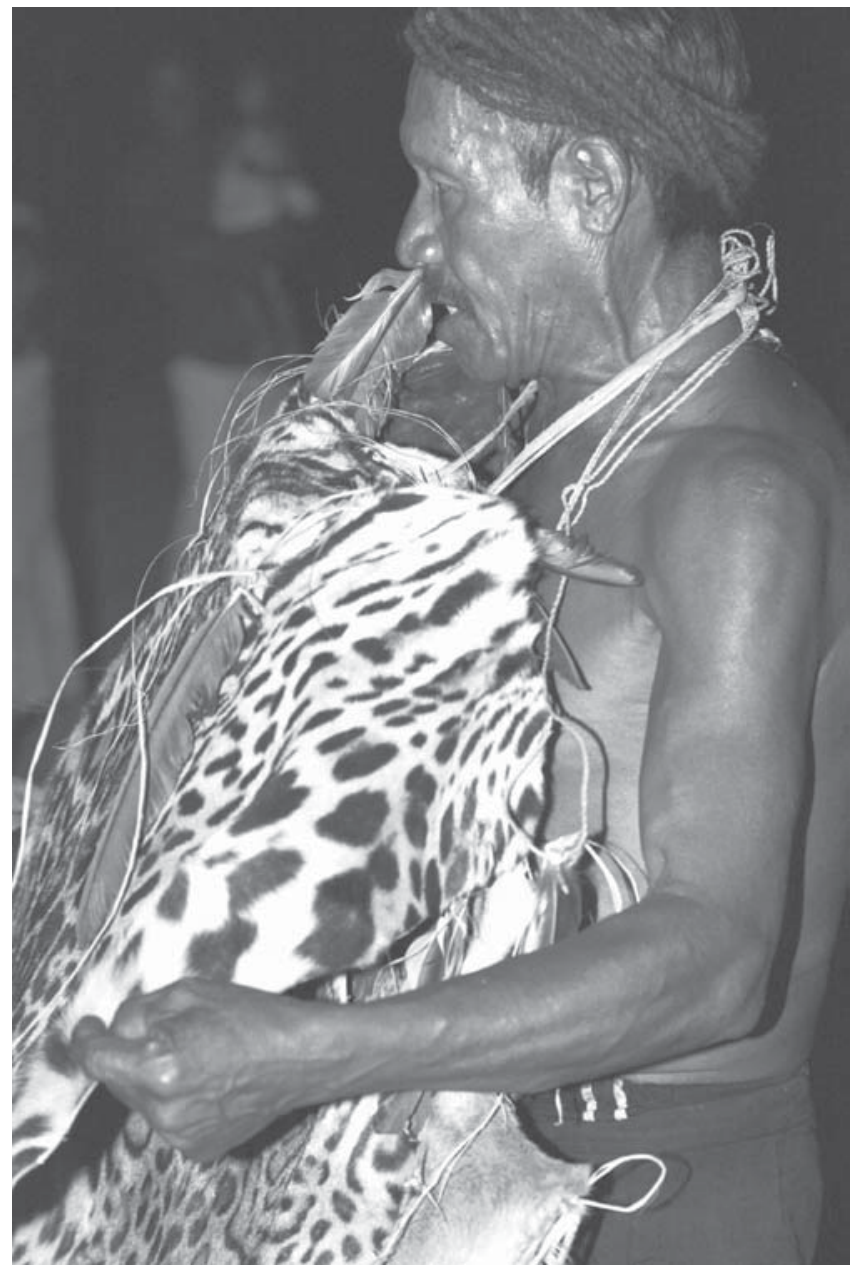

Figura 9: Uma das tarefas principais do representante do morto é caçar um grande felino, cuja pele será dada por ele aos parentes do finado. 
Revista de Antropologia, São Paulo, USP, 2006, v. 49 no 1.

\section{À guisa de conclusão}

Se simplificássemos as várias transformações desencadeadas pela morte, teríamos o seguinte quadro.

A morte é causada pelo bope - espírito comedor de carne crua, sangue e carniça. O bope, entidade responsável pelas grandes transformações naturais (nascimento, puberdade, morte), inicia assim o processo de desfiguração do corpo, do qual apenas sobram os ossos. Estes deverão ser limpos, pintados, ornamentados e rearranjados numa ordem específica num grande cesto de palha, que os Bororo denominam aroe j’aro, previamente confeccionado pela mãe ritual do morto. O crânio é a parte do corpo que recebe maior atenção. Depois de pintado de urucum e ornado com penas num arranjo que segue o padrão do clã a que pertencia o morto, o crânio é colocado sobre uma pequena bandeja de palha (baku), que deve ser posta na parte superior do cesto. A ordem dos ossos no cesto procura reproduzir a ordem da anatomia do corpo. Note-se ainda que a escarificação dos parentes do morto, que ocorre ao longo desse ritual em que os ossos são ornamentados, faz com que o próprio corpo dos enlutados de alguma forma se desfigure. Como compartilham de substâncias vitais com o finado, também os enlutados sofrem essa desfiguração.

Refigurado o morto, por meio do rearranjo de seus ossos, ele agora é aroe. No mundo dos vivos, é por meio de seu representante, o aroe maiwu, que ele aparece. Por outro lado, se a morte significa uma perda no mundo dos vivos, e o que o funeral faz é revelá-la, é também no funeral que são iniciados os jovens rapazes. Só depois de iniciados, eles são considerados adultos e podem se casar, ter filhos e participar plenamente da vida social bororo. Se a morte é uma perda, a iniciação é, de certa forma, um modo de reparar essa perda, habilitando mais indivíduos para a vida que deve continuar. 
Caiuby Novaes, S. Funerais entre os Bororo...

Finalmente, se a perda do sopro vital é o sinal mais claro da morte de uma pessoa para os Bororo, o que o aroe maiwu, representante do morto, fará em todos os funerais é soprar a cabacinha - powari-aroe-, confeccionada pelo pai ritual do morto e que lhe foi oferecida. O sopro que se extingue reaparece refigurado na cabacinha tocada pelo representante do morto.

O powari-aroe é o elemento que permite perceber que a identidade social só emerge através de um indivíduo concreto, com todas as suas idiossincrasias. Cada indivíduo é único em sua singularidade, assim como cada cabaça deve produzir os sons em um ritmo peculiar. Tal como o indivíduo em seu processo de constituição biológica, ela é confeccionada por um homem (o "pai" do aroe) e guardada por uma mulher (a "mãe" do aroe). $\mathrm{E}$, assim como o indivíduo bororo, a cabaça só aparece socialmente através de um outro, do aroe maiwu, representante social do morto e que deverá tocá-la em momentos rituais. (Caiuby Novaes, 1983, p. 311-12)

O funeral é, assim, em todos os sentidos, um momento muito especial para essa sociedade. Momento de recriação, de reafirmação estética, de conhecimento. Um conhecimento que se afirma e se difunde de modo específico, em que se percebe nitidamente que os sentidos do mundo passam pelos sentidos do corpo. ${ }^{10}$ Conhecimento em que o corpo é memória, em que a experiência sensível implica corpos, ações sobre o corpo, manipulações simbólicas e literais (as escarificações) sobre os corpos, fabricação de novos corpos. Conhecimento sinestésico em que se misturam as várias percepçôes de cheiros, cansaço, excitação, dor, cores, prazer estético, euforia, cantos e choros. Ao longo dos inúmeros rituais, é uma percepção de vida e sociedade que o funeral propicia. Como disse José Carlos na epígrafe deste texto: "Morreu devia acabar tudo, mas começa tudo outra vez, porque tem cabacinha". Nesse senti- 
do, o que o funeral bororo revela é uma seqüência de transformações, desmascaramentos e remascaramentos que reforçam os mistérios acerca da morte e da vida.

\section{Notas}

1 Agradeço a leitura e os comentários instigantes deste texto a Rose Satiko Gitirana Hikiji e especialmente a Andréa Claudia Marques Barbosa. Agradeço igualmente a Fernando Santos-Granero e a George Mentore pelos comentários a este artigo, depois que o apresentei no Congresso "In the World and about the World: Amerindian Modes of Knowledge", realizado na University of Virginia, em novembro de 2005, em homenagem a Joanna Overing.

2 A respeito dos cantos bororo, ver Caiuby Novaes (1998).

3 "It provides a focusing-mechanism, a method of mnemonics and a control for experience" (Douglas, 1966, p. 63).

4 A respeito do funeral bororo ver, entre outros, Viertler (1991), Crocker (1985), Caiuby Novaes (1983, 1994 e 1998).

5 Segundo Crocker, os Bororo percebem a realidade em termos de uma antítese filosófica que eles denominam bope e aroe. "The first involves the processes of physical change, exemplified by the growing of vegetables and the killing of animals, while the second dwells on the immutability of physical reality in its 'givenness' as the regularity of night and day, the seasons, natural species. For the Bororo human life requires the harmonious coordination of both principles, achieved as much by symbolic action as technical knowledge" (Crocker, 1985, p. 13).

6 A respeito dos rituais como momentos não apenas de expressão de sentido, mas igualmente de ação efetiva sobre o mundo, ver o artigo de Parkin (1992).

7 "He is shown the bullroarers which imitate the cries of these monsters and which the Bororo explicitly compare to giant phaluses" (Crocker, 1985, p. 106).

8 Ver, a respeito desse ritual e dos zunidores, Caiuby Novaes (1994).

9 Ver, a respeito do powari aroe e de outros elementos da cultura material presentes no funeral, Caiuby Novaes (1983).

10 Agradeço a John Dawsey as sugestôes para essa abordagem. 


\section{Bibliografia}

ALBISETTI, C. \& VENTURELLI, J. A.

1962 Enciclopédia Bororo, vol. I (Vocabulário e Etnografia), Campo Grande, Museu Regional Dom Bosco.

1976 Enciclopédia Bororo, vol. III, parte I (Cantos de caça e pesca), publicação n. 5. Campo Grande, Museu Regional Dom Bosco.

CAIUBY NOVAES, Sylvia

"Tranças, cabaças e couros no funeral Bororo; a propósito de um processo de constituição de identidade", in MARTINS, José de Souza (org.), A morte e os mortos na sociedade brasileira, São Paulo, Hucitec.

1994 "Aije - a expressão metafórica da sexualidade entre os Bororo", Revista de Antropologia, vol. 37.

1998 "Paisagem Bororo - de terra a território", in NIEMEYER, Ana Maria \& GODOY, Emília, Além dos territórios, Campinas, Mercado das Letras.

CROCKER, Christopher

1985 Vital Souls - Bororo Cosmology, Natural Symbolism and Shamanism, Tucson, The University of Arizona Press.

DOUGLAS, Mary

1966 Purity and Danger, an Analysis of Concepts of Pollution and Taboo, Londres, Routledge and Kegan Paul.

OVERING, Joanna

1991 "A estética da produção: o senso de comunidade entre os Cubeo e os Piaroa", Revista de Antropologia, vol. 34: 7-33.

PARKIN, David

1992

"Ritual as Spatial Direction and Bodily Division", in DE COPPET, Daniel, Understanding Rituals, Londres, Routledge, pp. 11-25.

TAUSSIG, Michael

Mimesis and Alterity - a Particular History of the Senses, Londres, Routledge.

1999

Defacement - Public Secrecy and the Labor of the Negative, Stanford, Stanford University Press. 
Revista de Antropologia, São Paulo, USP, 2006, v. 49 no 1.

VIERTLER, Renate B.

A refeição das almas, São Paulo, Hucitec/Edusp.

ABSTRACT: In this article I analyze Bororo funerals as moments of defacement and refacement (Taussig, 1999). Death triggers a series of transformations that involve the dead person, the corpse itself, the soul, the making of the deceased's representative, and the relationships among the living. All these transformations - which are the object of public secrecy - take place along the various rituals that compose the funerary ritual cycle. The text is accompanied by a selection of photographs taken by myself during 30 years of field research among the Bororo Indians of Mato Grosso, Brazil, in order to illustrate Bororo funerals as moments of recreation of the world, following the theoretical perspectives of Taussig (1999) and Overing (1989, 1990).

KEY-WORDS: Bororo funerals, processes of defacement and refacement, public secrecy, photographs of Bororo funerary rites.

Aceito em novembro de 2005. 